\title{
Increasing the Brand Awareness of PT. Banmadju Mandiriperkasa's Customers Through A Company Profile Video
}

\author{
Felix Octavius Saverino \\ English Department, Faculty of Letters, Petra Christian University, Siwalankerto 121-131, Surabaya \\ 60236, INDONESIA \\ E-mail: FelixOctaviusSaverino@gmail.com
}

\begin{abstract}
PT. Banmadju Mandiriperkasa is located at Jl. Pattimura 104b, Kediri. As a tyre retreading company, the main product of PT. Banmadju Mandiriperkasa are both hot and cold retreading systems. Meanwhile, the company also offers a complete tyre sizing for each category of a vehicle from sedan, minibus, bus, truck, forklift, and also OTR (Off the Road). The company's main problem is the intense competition between the competitors in the global retread tyre market, which causes PT. Banmadju Mandiriperkasa should increase brand awareness to the customers. Therefore, it is better to make a company profile video as a solution to overcome the company's problem. To gain awareness from the potential customer, the company profile video will be distributed by using social media such as WhatsApp, Instagram, Facebook, and YouTube. By having a company profile video, PT. Banmadju Mandiriperkasa can increase the brand awareness to the potential customers from all over Indonesia.
\end{abstract}

Keywords: retreading company, tyre, awareness, company profile video, potential customers.

\section{INTRODUCTION}

PT. Banmadju Mandiriperkasa is the leading and the oldest tyre retreading company in East Java, established in 1953, founded by the late Mr. Soeprapto. The first headquarter was in Setiabudi Street 5-7 Kediri, East Java, as the leading company. Providing professional development opportunities due to the high demand for market value to always give satisfaction in developing company services forces this company to add a new modern machine. Imported machines that come from Italy, Belgium, Germany, Auckland, and Malaysia. Thus in 1979, the headquarter was moved into a more comprehensive location in Pattimura Street 104B Kediri, East Java. While the first headquarters has become a marketing outlet and service center in the region of Kediri.

PT. Banmadju Mandiriperkasa offers five different types of retreading services regarding the size of the tyre in light truck, truck, sedan, forklift, and also OTR (Off the Road). Besides offering the five different types of retreading, PT. Banmadju Mandiriperkasa also comes up with two vulcanization methods, which is a hot process and a cold process. Moreover, the customers have spread all over Indonesia through all Java Island, including Bali and Lombok. Therefore, this company has a good reputation, quality, and services to provide the customers' best satisfaction.

Based on my interview with the Director of PT. Banmadju Mandiriperkasa, she claimed that the biggest competitor for PT. Banmadju Mandiriperkasa in East Java so far is CBM, Vulkanin Adi Jaya, and Sumber Mas Agung. Those three companies are new in doing retreading compared to PT. Banmadju Mandiriperkasa. As new and counted as a young age's competitors, those companies share almost the same price and quality to the customers. 
During my internship period, I found a serious problem concerning the company. There is intense competition from competitors in the global market, which causes PT. Banmadju Mandiriperkasa should increase brand awareness to customers. However, the agent also has a problem when making prospects because the agent does not have proper and adequate tools to introduce PT. Banmadju Mandiriperkasa, as well as strength or USP, to individual customers.

Until now, the company only provides the agents with the out-of-date catalog that belongs since the company was founded. The catalog has an old fashioned visual in terms of images, language, content, and no price at all in the catalog. Indeed, the agents have difficulties in gaining awareness from the customers because of the ineffective promotional tools. Therefore, as the company's main representative in marketing, agents need to be supported to give interesting information while prospecting the customers.

On the other hand, competitors such as CBM and Vulkanin Adi Jaya have complete marketing promotional tools in social media. To perform better against the global market, both competitors use YouTube, Instagram, Facebook, WhatsApp, and website. As a result, customers are more convinced to use their services rather than using a PT. Banmadju Mandiriperkasa's services. Therefore, I decided to make a company profile video as my Creative Thesis to overcome the company's problem. The solution to this issue is important because people will be more aware and familiar with PT. Banmadju Mandiriperkasa by making the company profile video and spreading it using all social media platforms like WhatsApp, Instagram, YouTube, and Facebook.

Then, people will be interested in using PT. Banmadju Mandiriperkasa's services because of the uniqueness and its strength of the products. Those will create a positive image for customers to become loyal to the company's services and always use PT. Banmadju Mandiriperkasa's retreading services. On the other hand, it will help agents do prospects in the customers by easily showing a company profile video to highlight the company's strength and uniqueness. In conclusion, a company profile video is an effective and powerful tool to increase PT. Banmadju Mandiriperkasa's brand awareness, reputation, and professionalism of the company.

In order to make and finish the project completely, there are some principles that I used in making the solution. I use some information from books and online sources to understand the definition, purposes, and features used in making a company profile video. The principles are used to provide my proposed project which is the company profile video for PT. Banmadju Mandiriperkasa.

\section{Brand and Branding}

A brand can be named a product or services, logo or a visual one represents to the public, or a customer's belief about certain products or services (Healey, 2008, p,7). A brand that exists in a customers' mind: it is a collection of perception about something. Based on the explanation above, the brand is the intangible that makes people love, trust, and believe the product of the company. The brand is not only about the logo, tagline, or trademark but, it is more than that which can affect customer's thoughts about that company. In other words, branding is about seizing every opportunity to tell why customers should choose certain brands over another. By doing branding, the company can also identify and emphasize its uniqueness and strengths to differentiate and make the company stand out from its competitors. It can be concluded that branding is the process to get customer attraction to buy products and to build brand awareness. Branding is the way to promote the company's brand to customers so they can believe and buy the products that the company offers. 
Saverino: Increasing the Brand Awareness of PT. Banmadju Mandiriperkasa's Customers Through a Company Profile Video

\section{Brand Awareness}

According to Kopp (2020), brand awareness is a marketing term that describes the degree of consumer recognition of a product by its name. Creating brand awareness is a key step in promoting a new product or reviving an older brand. Ideally, awareness of the brand may include the qualities that distinguish the product from its competition. Brand awareness refers to the familiarity of consumers with a particular product or service. A brand awareness campaign seeks to familiarize the public with a new or revised product and differentiate it from the competition. Social media has become an important new tool in brand awareness marketing.

\section{Levels of Brand Awareness}

According to Zielski (2010), there are six different levels of brand awareness, such as: Brand Rejection: if people connect a brand with unpleasant or harmful, people will actively ignore the product. The negative perception of loyal customers can result in a destructive impact on the brand.

Brand Unrecognized, this is because the buyers did not actually know the name or perhaps because it is not easily distinguished from the competitors. Find the disparity in value between one of the companies and competitors, and do not forget to highlight the value.

Brand Recognition is a decent stage to reach if there is not any recognition at the brand at all. Name awareness will make consumers lean towards the product and provide the alternative between one product and one that people never heard of.

Brand Preference, this is where customers are given the choice of two brands, customers will choose one product between someone else's products. The marketing should add every value that the product or services has, making people easily decide to choose one product over another.

Brand Loyalty, at this stage customers can prefer one brand over all the other products out there and repeat orders, even though people may have experienced occasional bad service or different needs. In fact, this is the durability of the brand that all people want. In order to achieve brand loyalty, people need to have a strongly distinguished product with a lot of added value.

Top of mind is the highest level of brand awareness because the brand can dominate people's minds and pops up for the first time in a specific product or service. In conclusion, the brand is already registered in the customer's mind, so the brand that has been chosen is unbeatable among the others.

\section{Promotion}

Promotion is included in the concept of Marketing Mix, along with product, price, and place. According to (Kuenn \& Kuenn, 2015, p.136-137), promotion is about communicating the value of content to the people who will be able to share it with their own networks. Promotion is the work of announcing what will people have to offer and ensuring that it gets distributed to those who want to see it. Promotion consists of three essential components. Those are the objectives, strategies, and policies or can be concluded as a promotional mix.

\section{Promotional Tools}

Promotional tools are consisting of three meanings, which are advertising, publicity, and sales promotion. Companies commonly use those media to promote their products to the customers. A promotional tool will inform the customers about the existence of the products and develop its company's brand awareness. (Mac Kenzie, 2002, p. 60-62). Moreover, there are five different kinds of promotional tools. The first one uses traditional media such as newspapers, magazines, and brochures, then spreading it to the target market. Second is digital technology; it uses mobile devices to make promotional tools and online applications to promote something. 
The applications or platforms include websites and social media such as Instagram, Facebook, Twitter, WhatsApp, Line, YouTube, etc. Third is public relations, which means companies will use newsletters, press conferences, and news reports. Fourth is events, for example, sponsoring events and community activities. The last one is called salespeople find influencers, for example, doing endorsement to some public figures or celebrities to promote its product or services.

\section{Unique Selling Points}

According to new research about USP (Economic Times, 2018), Unique Selling Proposition or USP is the one feature or the perceived benefit of a good, making it unique from the rest of the competing brands in the market. It is the reason which motivates a buyer to purchase a product even though it might be more expensive than other products. A strong, unique selling proposition makes a brand stand apart and plays a vital role in branding a product. USP alone can guarantee a product's success. In this case, a distinct USP can differentiate the value of a company from its competitors. There is no worry about competition anymore because if the company has developed something that others have not developed, then the company has become the only player or a market leader in that specific product.

\section{Company Profile Videos}

Company profile videos are powerful tools that effectively showcase a brand and build trust for customers to choose one over another competitor to reach a goal or solve a problem. In research from Team (2020), company profile video can also boost brand engagement, increase trust in a company, and is a trend that is not going anywhere or anytime. These days in society, people have interacted with customers through television, newspaper ads, sales brochures, radio, and magazines. A company profile video is a prime opportunity for brands and companies to cast a more comprehensive, useful net over their target customers by creating a company profile video. A good company profile video has the power to convert potential customers and stakeholders more effectively and efficiently. Company profile video is a short synopsis of the brand and what the company looks like, also what it has to offer to the customer. In order to make a good company profile, it is needed to be original and always allow the actual brand identity to voice and shine through videos.

\section{METHOD}

\section{Respondent's Criteria}

In the data collection process, I use two different methods in order to arrive at the solution. First, I did an online survey because of the pandemic COVID-19, the customers filled the survey by using a google form that spread through WhatsApp and E-mail. As for the corporation, government, and community organizations, the company representatives are the one who fulfilled the questionnaire. It is the easiest way and very practical to get the data for online surveys by using google form instead of any other method. I conducted this survey over a week, and as a result, I got a total of forty-one respondents. The second method I used to collect the data by conducting a meeting with the company's director and manager. I used this to match and compare with the customers opinion and company's representative feedback. Therefore, I could get valid results regarding the company's strengths, weaknesses, and also USP.

\section{Methods of Data Collection}

The data was collected by giving questionnaires to the customers, due to the pandemic of COVID-19 the questionnaire was done online via google form. There are four section in the questionnaire. The first section of the questionnaire is about the personal data of the respondent. There are several questions about the customers' background, such as a company or individual name, phone number, in which city the company is located, and job status. Secondly, is about the company's perception from the customer's point of view. There will be a question for product, 
Saverino: Increasing the Brand Awareness of PT. Banmadju Mandiriperkasa's Customers Through a Company Profile Video

services, company strength, weakness, and uniqueness. Third, it is about the promotional tools that will be useful for the company and customers. Lastly, there are also several questions about the WhatsApp platform as to share the video and about the interesting scene that will show inside of the company profile video.

\section{FINDING AND DISCUSSION}

\section{Result of the Questionnaire}

The first question is about the personal data of the respondent. There are several questions about the customers' background, such as a company or individual name, phone number, in which city the company is located, and job status.

\begin{tabular}{|l|l|l|l|}
\hline $\begin{array}{l}\text { P O } \\
\text { NUSANTARA }\end{array}$ & 085641264416 & $\begin{array}{l}\text { Pemilik Angkutan / } \\
\text { Ekspedisi }\end{array}$ & KUDUS \\
\hline $\begin{array}{l}\text { MAJU JAYA } \\
\text { ABADI }\end{array}$ & 081225885022 & $\begin{array}{l}\text { Agen Perusahaan } \\
\text { PT. BANMADJU }\end{array}$ & REMBANG \\
\hline $\begin{array}{l}\text { LANA } \\
\text { SUPRAPTO }\end{array}$ & 081575134883 & Individu & KUDUS \\
\hline Rich Tyre & 081328556886 & $\begin{array}{l}\text { Agen Perusahaan } \\
\text { PT. BANMADJU }\end{array}$ & Solo \\
\hline Handoko & 081575653486 & Individu & SEMARANG \\
\hline Lautan Ban & 0816607687 & $\begin{array}{l}\text { Retailer (Toko Ban, } \\
\text { Variasi Mobil, dsb) }\end{array}$ & Bandung \\
\hline
\end{tabular}

\begin{tabular}{|l|l|l|l|}
\hline Gunawan T & 085655524984 & $\begin{array}{l}\text { Retailer (Toko Ban, } \\
\text { Variasi Mobil, dsb) }\end{array}$ & Surabaya \\
\hline SARINADI & 082177400777 & $\begin{array}{l}\text { Retailer (Toko Ban, } \\
\text { Variasi Mobil, dsb) }\end{array}$ & Bali \\
\hline Khoe Irfan & 082143495857 & $\begin{array}{l}\text { Agen Perusahaan } \\
\text { PT. BANMADJU }\end{array}$ & Jakarta \\
\hline BALI RAYA & 081222005341 & $\begin{array}{l}\text { Agen Perusahaan } \\
\text { PT. BANMADJU }\end{array}$ & Bali \\
\hline $\begin{array}{l}\text { TOKO } \\
\text { NEGARA } \\
\text { MOTOR }\end{array}$ & 087765957839 & $\begin{array}{l}\text { Retailer (Toko Ban, } \\
\text { Variasi Mobil, dsb) }\end{array}$ & BALI \\
\hline $\begin{array}{l}\text { PT. Multi } \\
\text { Internusa }\end{array}$ & 08117384056 & $\begin{array}{l}\text { Kontraktor } \\
\text { Bangunan }\end{array}$ & Jakarta \\
\hline $\begin{array}{l}\text { SUMBER } \\
\text { HARAPAN }\end{array}$ & 081327114908 & $\begin{array}{l}\text { Pemilik Angkutan / } \\
\text { Ekspedisi }\end{array}$ & SEMARANG \\
\hline
\end{tabular}
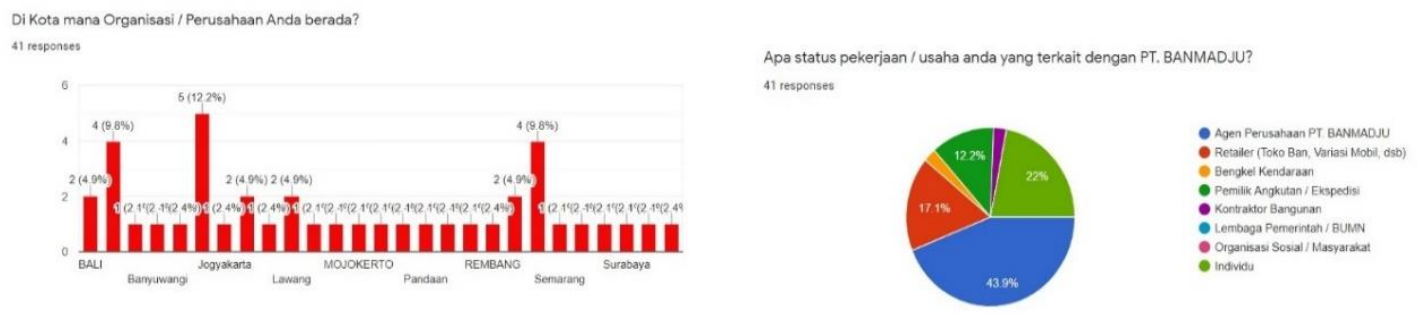

Based on the survey above, it can be seen clearly that the customers were genuinely spread from all over Java, Bali, and Lombok Island. Most of the customer's demand is from Bali with six votes, the next is Jakarta with five votes, and the third one is Surabaya with four votes. Those are the top three marketplaces in all around Indonesia for PT. Banmadju Mandiriperkasa's retreading product. The rest of the customers were balanced and widespread in all cities around Indonesia. Then, as seen in the result above, there are six multiple-choice related to each customer's job status. The results are $43,9 \%$ is work as company agents, $22 \%$ is for individual use, $17,1 \%$ is from the retailer of the tyre shop, $12,2 \%$ is from the expedition and transport, $2,5 \%$ is from the car workshop, and 2,3\% is from a contractor. The rest of the two choices did not vote by therespondents as community organizations and government use. Based on the answers, it is clearthat the demand and market segmentation came from those six categories. Therefore, PT. Banmadju Mandiriperkasa needs to be concerned when adjusting the product to its target market based on this survey.

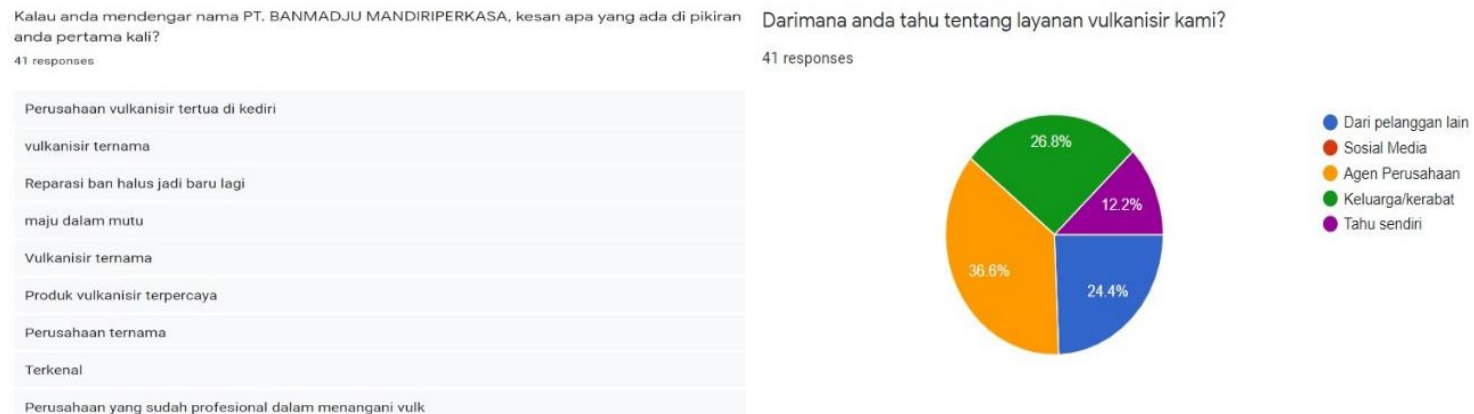


Banmadju Mandiriperkasa is well known for its tyre retreading services. Therefore, I conclude that PT. Banmadju Mandiriperkasa has succeeded in proving its professionalism in doing tyre retreading to provide good quality to the customer. Hence, this can be an excellent opportunity to reach the top-of-mind levels in promoting potential customers. The next question is about how customers know about PT. Banmadju Mandiriperkasa's services. As a result, it shows that the most dominant promotion is from the agents, which $36.6 \%$, next is from friends or family that result in $26.8 \%$, and then the third one is from the fellow customers with a total of $24.4 \%$. Lastly, the customer knows by themselves with a percentage of $12,2 \%$. Therefore, the company must help the agents in order to increase brand awareness even more than these results.

At the section three, respondents also voted about the reason for using the PT. Banmadju Mandiriperkasa's services are because of the good quality rubber with 28 votes $(68.3 \%)$. From the survey, it can be concluded that the company's strength is attributable to its good quality of rubber. Even their impression also mentions a high price, but the good quality of rubber is still an essential factor that can be used as the USP of the company's product. The second question also voted by $56.1 \%$ respondent that choosing the quality is a company's main advantage.

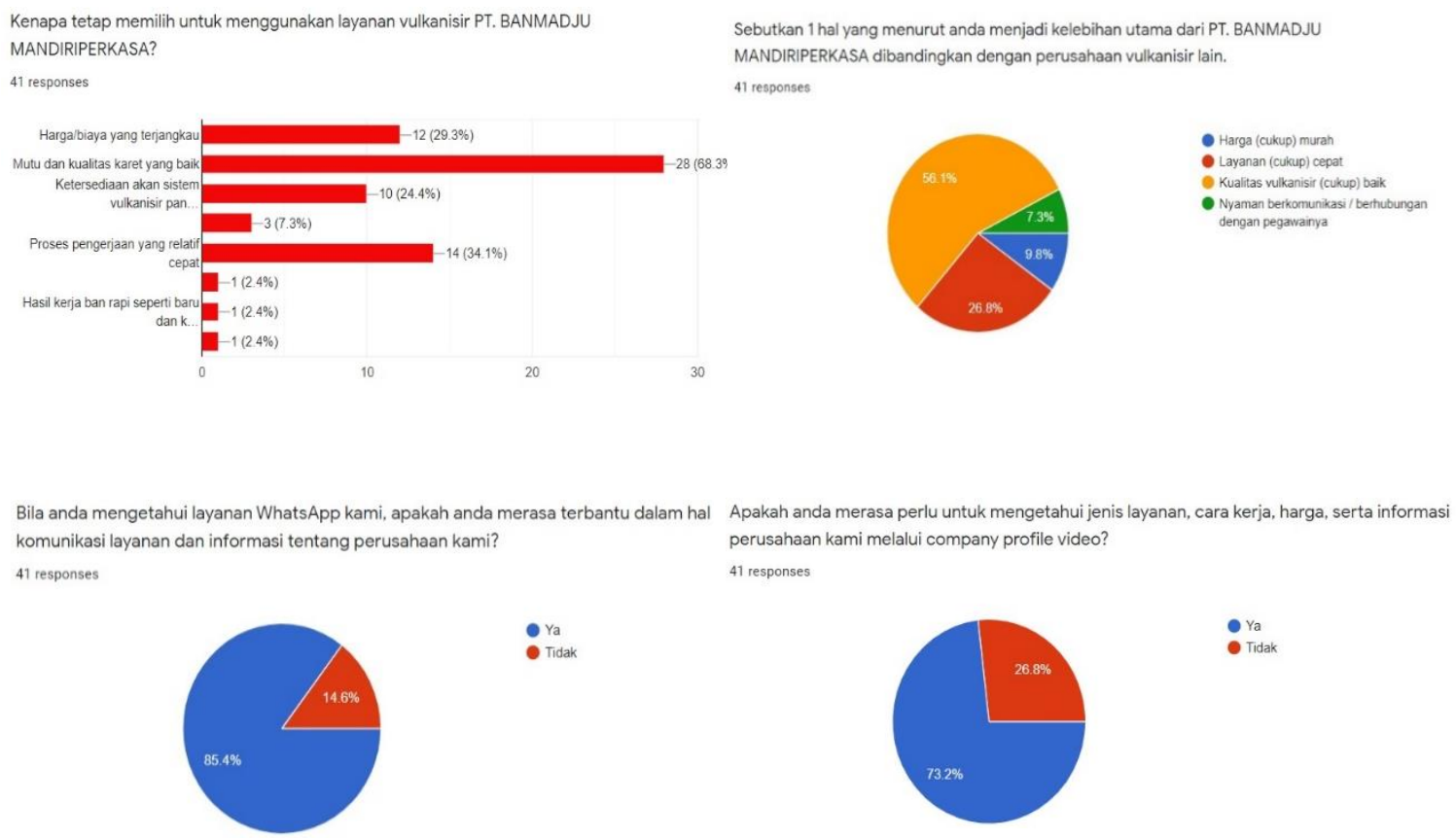

Seberapa tertariknya anda untuk melihat perusahaan kami melalui company profile video?

Apabila perusahaan akan membuat company profile video, hal apa yang menurut anda paling 41 responses

menarik dan penting untuk diliput dalam video?

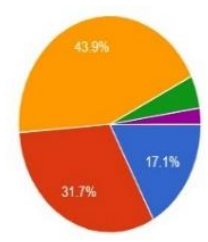

41 responses

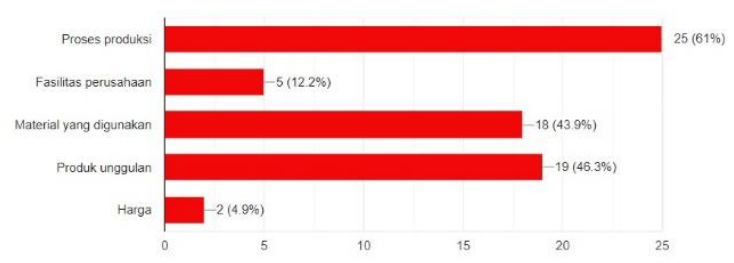

The last section of my questionnaire is about how the respondent's assumptions about PT. Banmadju Mandiriperkasa's current promotion tools. The majority of respondents also already know about the WhatsApp account that is owned by the company. It can be confirmed through the answer results that most of the respondents voted yes with a percentage of $85,4 \%$ and followed by no answer $14.6 \%$. It can be concluded that the existence of the company's WhatsApp account 
Saverino: Increasing the Brand Awareness of PT. Banmadju Mandiriperkasa's Customers Through a Company Profile Video

can help a lot in sharing the videos, which is more practical and efficient. In the last question shows that indeed company profile video is the right promotional tool for PT. Banmadju Mandiriperkasa. As a result, most of the respondents voted yes about the interest of seeing the company profile video with a percentage of $73.2 \%$ and $26.8 \%$ for the no answer.

In conclusion, I believe promoting this company by highlighting its uniqueness in a company profile video is the right solution to increase PT. Banmadju Mandiriperkasa's brand awareness to its target market.

\section{Result of the SWOT Analysis}

Based on the SWOT Analysis, there were three USP's that were found in PT. Banmadju Mandiriperkasa. The first USP is PT. Banmadju Mandiriperkasa has a good quality of products from 1953 until now. The second USP is PT. Banmadju Mandiriperkasa has a complete offer regarding the production process, which are both hot and cold process. The third USP is PT. Banmadju Mandiriperkasa offers various sizes of tyres such as Sedan, Light Truck, Truck, OTR (Off the Road), and Forklift tyres.

\section{Explanation of Each Scene in the Promotional Video}

Inside the storyboard, there are six big scenes such as the product, "Who are we?", "How do we work?", products with the hot process and various sizes of tyres, "How to Contact Us?", and Conclusion. Each scene consists of its footage description of the products and services.

The first scene at the beginning of the video is the company's building with the logo. It is important to grab the viewers' attention to the company's visual in the opening scene. Then, I moved to the product demonstration that was located inside of the company. Here, I put some demonstration related to the tyre retreading that has been produced by PT. Banmadju Mandiriperkasa. The manager is the one in charge of handling the demo scene because he has to convince the viewers by doing speak and act. The next footage shows that our products are much better in quality and visual than other competitors. Therefore, the company will have no doubt in competing against competitors in the global market. That footage will give the viewers a positive perception of the company's strong, durable, and neat product.

The second scene is about "Who are we?" that contains the company's introduction. Moreover, the footage will be all about the company building and inside, like the machine and employees. The main purpose is to show that the PT. Banmadju Mandiriperkasa has been in the business for quite a long time, with its professionalism and in-depth experience in the tyre retreading industry. Lastly, the footage will show the company's location to the viewers with google maps. Most of the people did not know the company location because the address is not available on google maps. It also helps to inform the viewers about the easy access in the main street of Kediri City.

The third scene is about "How do we work?" at this part, the videos will show the retreading process along with a complete procedure. The production process plays a vital role in a big company like PT. Banmadju Mandiriperkasa. Therefore, the viewers need to know about our employees' technique and professional work on doing retreading. I give a description and its name for every step that shows in the footage. For example, like Tyre Inspection as the heading and then the description uses the Indonesian language below, "Penentuan proses vulkanisir dengan proses panas atau dingin". Then, it also works for the different processes which are hot and cold. At the bottom of the heading in the building step, I will write "Penempelan Tread Liner (Proses Dingin)" and "Penempelan Tread Liner (Proses Panas).

The fourth scene is showing that the company not only offers the cold process but also produces products with the hot process. Then, it is followed by various sizes of tyres because 
those two scenes are considered similar. I decided to put it together as the footage and related it to the screen. The footage might emphasize and highlight the hot processes uniqueness that nowadays is being rarely owned by other competitors. Therefore, customers can have many options according to their needs. Besides, the voiceover will give a clear insight into why they must choose the hot process rather than the cold process. It is because the hot process has a more affordable price compared to the cold process. Lastly, the hot process is the only choice when tyres cannot be processed with the cold retreading system except forklift and OTR tyres.

The fifth scene is about "How to Contact Us?" This section aims to easily help the viewers get the agents' contact information. Then, it also shows that our target market is all around Java, Bali, and Lombok Island. When the viewers want to ask for further information, they can easily call or send a WhatsApp message to the company or agent number available on the screen.

The last scene is the conclusion speech from the manager that conducts a demo product at the beginning. He will give a brief summary and make a call to action to end the video. Then, at the end of the scene, it will smoothly appear company logos along with the motto. Since the customers of PT. Banmadju Mandiriperkasa is mostly Indonesian people. It is better to use the Indonesian language in the voice-over features inside the video. The English language is then used as a subtitle of the video to make the company professional and beneficial if the viewer does not understand the Indonesian language. Therefore, the videos might effectively use both languages to deliver powerful and complete information to all the viewers.

\section{CONCLUSION}

I decided to make a company profile video to solve PT. Banmadju Mandiriperkasa's main problem which is to increase the brand awareness to its potential customers. I chose to make a company profile video because the video is indeed more interesting and effective in terms of visual, voice, text, and content all together in one video. Besides, the company profile video will highlight the company's uniqueness, strength, best seller products, and production process. Next, once it is finished, the company profile video could be shared on all digital platforms like WhatsApp, Instagram, Facebook, and even YouTube. In conclusion, a company profile video is the best solution to boost the awareness of PT. Banmadju Mandiriperkasa to the potential customers.

\section{REFERENCES}

Economic Times. (2018, December 18). What is Unique Selling Proposition? Definition of Unique Selling Proposition, Unique Selling Proposition Meaning. Retrieved from https://economictimes.indiatimes.com/definition /unique-selling-proposition

Healey, M. (2008). What is branding? Singapore: RotoVision SA.

Kopp, C. M. (2020, July 26). Why Brand Awareness Matters. Retrieved from https://www.investopedia.com/terms/b/brandawareness.asp

Kuenn, A., \& Kuenn, B. (2015). Content Marketing Works: 8 Steps to Transform Your Business (Vol. p.136-137). Phoenix, Arizona: Vertical Measures.

Mac Kenzie, I. (2002). English for Business Studies: A course for Business Studies and Economics Students. United Kingdom: Cambridge University Press.

Team, F. (2020, January 11). Company Profile Video: What is it, and why do you need one? Retrieved from https://thefreshink.com/why-company-profile-video

Zielski, D. (2010, March 12). Five Levels of Brand Recognition. Retrieved from http://www.oneworldsocialmedia.com/five-levels-of-brand-recognition/ 